\title{
Current Evidence of the Monoaminergic Regulation of Romantic Love and Relationship
}

\author{
Wei-Hsi Chen ${ }^{1,2}$, Mei-Yen Chu1,3, Yuan-Hsiang Chu1, Yen-Chin Lin', Kuo-Yen Chen ${ }^{1 *}$ \\ ${ }^{1}$ Graduate School of Human Sexuality, Shu-Te University, Taiwan \\ ${ }^{2}$ Department of Neurology, Kaohsiung Chang Gung Memorial Hospital, and College of Medicine, Chang Gung University, \\ Taiwan \\ ${ }^{3}$ Life Education Center, Chang Jung Senior High School, Taiwan \\ Email: ${ }^{*}$ 7748686@stu.edu.tw
}

How to cite this paper: Chen, W.-H., Chu, M.-Y., Chu, Y.-H., Lin, Y.-C. and Chen, K.-Y. (2017) Current Evidence of the Monoaminergic Regulation of Romantic Love and Relationship. Advances in Sexual Medicine, 7, 139-152.

https://doi.org/10.4236/asm.2017.73011

Received: June 26, 2017

Accepted: July 18, 2017

Published: July 21, 2017

Copyright $\odot 2017$ by authors and Scientific Research Publishing Inc. This work is licensed under the Creative Commons Attribution International License (CC BY 4.0).

http://creativecommons.org/licenses/by/4.0/

\begin{abstract}
Introduction: Sexual response cycle is modulated by a variety of biological factors, especially antidepressants and antipsychotics. Although the circuit of romantic love has recently been delineated, the biological impact on romantic love is barely mentioned in human, however. Methods: In thus study, a comprehensive literature review was completed to elucidate the role of central monoamines, including dopamine, serotonin, norepinephrine, epinephrine, melatonin and histamine, for the romantic love and relationship in human. Results: The central circuit of romantic love includes the mesolimbic and mesocortical tract and their extensions widely distributed in cortical, subcortical and brainstem structures. The activation of brain foci progressively decreases along with the romantic relationship in many areas, including the bilateral caudate and ventral tegmentum area without change of passionate love. Hyperactivity of dopamine and serotonin is suggested at the synaptic level for romantic love in lovers, probably through an inhibition of transporters or increase of terminal release. Romantic love can be modulated by antidepressants or recreational drugs. Polymorphism of dopamine and serotonin receptor relates to the romantic relationship. The effect of other monoamines is barely mentioned. Conclusions: Romantic love is vulnerable for secondary effect, such as drugs which modulate the dopamine and serotonin, in human. Romantic relationship is also impacted by the polymorphism of monoamine receptors. Therefore, the biological effect is not limited to sexual response cycle but also the romantic love and relationship. Further investigation is warranted for understanding the secondary effect in romantic love for romantic dissolution or divorce.
\end{abstract}

\section{Keywords}

Romantic Love, Passionate Love, Love, Dopamine, Serotonin 


\section{Introduction}

Social emotion evolutionally changes to respond and adapt the social environment, such as shame, guilty, trust or altruism in group. In an attempt to survive and propagate the human species, Homo sapiens also generates a few biological strategies in naturally polygamous men and monogamous women [1]. In order to provide a stable family for security, caring and feeding, romantic love evolves and serves for sexual attraction, bonding and attachment [1] [2]. Romantic love is most likely a human universal although its value and manifestations are culturally frameworked in different generations and societies [3].

It has been well known that the sexual response cycle can be modulated by a variety of external factors, such as prescriptions and medical disorders, through a modification of the central monoamines. The most common one is the use of antidepressants [4] or antipsychotics [5] which increases the synaptic serotonin (5HT) level or decreases the activity of dopamine (DA) and norepinephrine (NE) at the prefrontal and orbitofrontal cortex. Recently, functional technology successfully reveals the neural circuit of romantic love which encompasses multiple brain foci widely distributed in brainstem, limbic system and neocortex in a few studies [6]. If so, romantic love is expected to be affected when these neural substrates are involved. Surprisingly, secondary effect, such as drug, diet or other exogenous source, is barely mentioned for any impact for romantic love.

In this study, we attempt to review the literature in order to elucidate the relationship between central monoamines, including DA, 5HT, NE, epinephrine, histamine, and melatonin, and romantic love. The results are expected to provide noteworthy evidence for the monoaminergic regulation of romantic love and secondary involvement of romantic dissolution or divorce.

\section{Central Circuit of Romantic Love in Human}

Recently, functional magnetic resonance imaging (fMRI) is used to delineate the central neurocircuits of romantic love in human. Although the methodology is not completely identical in those studies, consistent results are still found amongst romantic lovers [6].

In rest state, brain activation is significantly detected at the dorsal anterior cingulate gyrus in in-lovers under resting state [7].

Under visual-stimulation by viewing partner's pictures, the caudate nucleus (including head, body or tail) is reported to be activated in more than $85 \%$ of in-lovers and the leading site of activation, following by ventral tegmentum area in $70 \%$, anterior cingulate gyrus, posterior cingulate gyrus, cerebellar hemisphere in 57\%, prefrontal cortex, medial frontal cortex, cerebellar vermis, hippocampus, insula in $42 \%$ and superior frontal gyrus, frontal subgyrus, hypothalamus, and putamen in $28 \%$, respectively. On the other hand, the right prefrontal cortex and bilateral amygdala are separately reported to be deactivated in $75 \%$ of in-lovers and the leading sites of deactivation, following by the nucleus accumbens, superior frontal gyrus, parallel or intraparietal sulcus, superior/middle temporal gyrus (including parieto-temporo-occipital region), rolandic opercu- 
lum in $50 \%$, caudate nucleus, medial frontal cortex, parietal lobe, precuneus, insula, angular gyrus, middle frontal gyrus, and posterior cingulate gyrus in $25 \%$, respectively [8]-[14].

Under audio-stimulation by hearing partner's name, activation is seen at bilateral caudate nucleus, ventral tegmentum area, insula, fusiform and hippocampal formation, right angular gyrus, and left inferior temporal gyrus, dorsal middle frontal gyrus, occipital lobe, and cerebellum [15].

In all index studies, the magnitude of romantic love is evaluated by the Passionate Love Scale and all participants are highly scored. These results suggest three points. Firstly, the anterior cingulate gyrus is upregulated during in-love and that reflects it governing the emotion and affection component of romantic love. Secondly, the mesolimbic system, including ventral tegmentum area and caudate nucleus, and the mesocortical pathway are also largely activated in lovers. Accordingly, the paleomammalian limbic system generates and maintains reward and motivation for romantic love, such as passion, obsessive and pleasure. Thirdly, since the majority of the mesolimbic and mesocortical tracts are DAergic neurons [16], the occurrence and magnitude of romantic love is therefore proposed to be mainly regulated by the DAergism. The NE, $5 \mathrm{HT}$ and other monoamines may also modulate the romantic love through their innervations on the ventral tegmentum area, mesolimbic/mesocortical tract or cortex.

\section{Brain Activity and Time Course in Romantic Love}

Functional neuroimaging studies show that the ventral tegmentum area, caudate nucleus, anterior and posterior cingulate gyrus, left frontal lobe, insula, cerebellum and parietal lobe activate, whereas amygdala, medial orbitofrontal cortex, prefrontal cortex and nucleus accumbens deactivate in the early phase of romantic relationship [9] [10] [12] [13]. The intensity of activation progressively decreases, first in caudate and then in ventral tegmentum area and other areas, along with the course of relationship. On the other hand, the intensity of deactivation does not change. In late phase, activation starts in hippocampus whereas deactivation in right superior/middle temporal gyrus [11] [14].

In long-termed relationship, the intensity of activation decreases more in the left caudate, ventral tegmentum area, cerebellum and parietal lobe whereas of deactivation in the amygdala, medial orbitofrontal cortex, and right superior/ middle temporal gyrus [8]. The predominant mesolimbic and mesocorticalDAergism gradually decreases along with the course of relationship, such as starting from right caudate, left caudate and then the ventral tegmentum area. However, it is interesting that the magnitude of love is still high in the longtermed romantic partners.

In fact, behavior is different between the early and late stage of romantic relationship. In the early stage, romantic lovers show characteristic features [17] [18] [19] [20], including excitement, euphoria, high passion, intimacy, obsession, preoccupation similar to addiction [17] [19], and insecurity [19] [20]. Risky behaviors are ensued for dealing with competition and possession. In the late stage, 
attachment love accompanies and implements with romantic love [20] to generate secure and spiritual bond, such as safety, balance of feeling, tranquility, commitment, intimacy [17], calmness and empathy [19] [21]. DA is known to cross-talk with a few neuropeptides, especially the oxytocin, in ventral striatum to initiate and promote attachment [22] [23]. Therefore, a mild decline and then plateau of mesolimbic and mesocortical DAergism from early to late stage of romantic relationship may represent a shift of infatuation and other obsessive behaviors to harmonic interaction in romantic lovers although passion decreases but still preserves.

\section{Literature Search and Results of Monoaminergic Regulation of Romantic Love and Relationship}

The aim of this study was to elucidate the effect of monoamines on romantic love and relationship. A systematic literature review following the guidelines of Preferred Reporting Items for Systematic Reviews and Meta-Analyses (PRISMA) was performed. The main interests were to find out the relationship between central monoamines and romantic love and romantic relationship in human.

\subsection{Monoamines Neurotransmitters}

Monoamine neurotransmitters are chemicals for neurotransmission. Structurally, they contain one amino group that is connected to an aromatic ring by a two-carbon chain $\left(-\mathrm{CH}_{2}-\mathrm{CH}_{2}-\right)$. All monoamines are derived from aromatic amino acids like tyrosine, tryptophan and phenylalanine, and the thyroid hormones by the action of aromatic amino acid decarboxylase. The classical central monoamines are dopamine, serotonin, norepinephrine (noradrenaline), epinephrine (adrenaline), histamine and melatonin. They are rich in the brain. Trace amount of other monoamines include $\mathrm{N}$-methylphenethylamine, phenethylamine, phenylethanolamine, m-tyramine, p-tyramine, 3-methoxytyramine, $\mathrm{N}$-methyltyramine, m-octopamine, p-octopamine, synephrine, 3-iodothyronamine and tryptamine. In this study, all the classical and trace monoamines were included.

\subsection{Literature Search}

A computer-based search of the literature was performed. Two groups of keywords were cross-matched. The first group of keywords was any classical and trace central monoamines, including "dopamine", "serotonin", "norepinephrine", "noradrenaline", "epinephrine", "adrenaline", histamine", "melatonin", "N-methylphenethylamine", "phenethylamine", "phenylethanolamine", "m-tyramine", "p-tyramine", "3-methoxytyramine", "N-methyltyramine", "m-octopamine", "p-octopamine", "synephrine", "tryptamine", or "3-iodothyronamine". The second group of keywords was "romantic love", "romance", "romantic" or "passionate love". The English scientific databases were PUBMED and Cochrane Database of Systematic Reviews. The Chinese scientific databases included the Airiti Library (http://www.airitilibrary.com) and Taiwan Periodical Literature 
System (http://readopac.ncl.edu.tw/nclJournal).

To obtain a large pool of data, all papers, books, proceedings, and abstracts that were published before December 2016 were considered in this study. Additionally, the references of each manuscript, book chapter and proceeding were further reviewed to ensure coverage of the literature.

\subsection{Results}

After an exclusion of reviews, comments, duplications, ex vivo study and human report without monoamine study, there were a total of 9 publications eligible, including 1 positron emission tomography study of central monoaminergic dynamic, 2 studies of transporter change, 4 studies of romantic relationship and genetics of monoaminergic receptors, and 2 studies of drugs and romantic love (Figure 1). They were summarized in Table 1 and discussed separately at under paragraphs.

\section{Central Monoaminergic Dynamic and Romantic Love}

The first and only study of positron emission tomography (PET) of central neurotransmitters in romantic relationship is DA. Takahashi et al. [24] used [11C] raclopride (a dopamine $\mathrm{D} 2 / \mathrm{D} 3$ receptor antagonist) to investigate the DA dy-

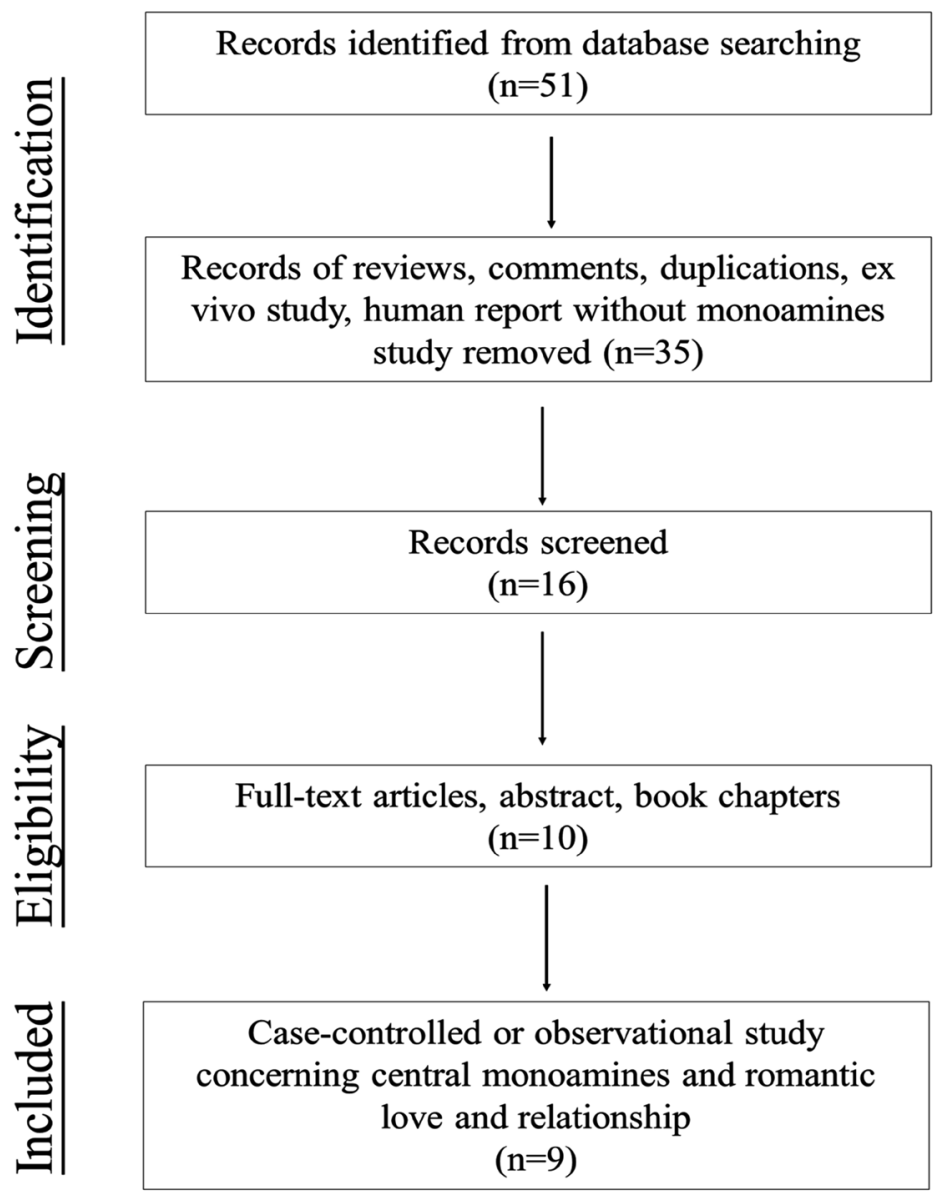

Figure 1. The selection process according to the PRISMA. 
Table 1. The summary of results between central monoamines and romantic love and relationship in human study.

\begin{tabular}{|c|c|c|c|}
\hline $\begin{array}{c}\text { Author(s) } \\
\text { Year }\end{array}$ & $\begin{array}{c}\text { Case } \\
\text { number }\end{array}$ & Results & Conclusions \\
\hline \multirow[b]{2}{*}{$\begin{array}{l}\text { Takahashi } \\
\text { et al. } \\
2015[23]\end{array}$} & & 1. Romantic love & \multirow[b]{2}{*}{$\begin{array}{l}\text { dopaminergic } \mathrm{D} 2 / \mathrm{D} 3 \\
\text { modulates the rewarding } \\
\text { experience of romance in } \\
\text { both early and late phase } \\
\text { of romantic relationship }\end{array}$} \\
\hline & $\begin{array}{c}6 \text { men and } 4 \\
\text { women }\end{array}$ & $\begin{array}{l}\text { visual stimulation of } \\
\text { partner's photo increased } \\
\text { the dopamine dynamics at } \\
\text { the mOFC and mPC in } \\
\text { lovers who committed } \\
\text { romantic relationship for } \\
2 \text { to } 125 \text { months }\end{array}$ & \\
\hline $\begin{array}{l}\text { Marazziti et } \\
\text { al. } 2016[30]\end{array}$ & $\begin{array}{l}30 \text { in-lovers less } \\
\text { than and } 30 \\
\text { in-lovers more } \\
\text { than } 6 \text { months } \\
\text { relationship; } \\
\text { women and men } \\
\text { are equal in both } \\
\text { groups }\end{array}$ & $\begin{array}{l}\text { lymphocytic DAT } \\
\text { decreased whereas DA in } \\
\text { early phase than late } \\
\text { phase of relationship }\end{array}$ & $\begin{array}{l}\text { increase of DA though a } \\
\text { suppression of DAT } \\
\text { occurs in early phase } \\
\text { of relationship }\end{array}$ \\
\hline $\begin{array}{l}\text { Marazziti et } \\
\text { al. } 1999 \text { [31] }\end{array}$ & $\begin{array}{l}20 \text { in-lovers less } \\
\text { than } 6 \text { months } \\
\text { relationship, } 20 \\
\text { OCD patients, } 20 \\
\text { non-lover }\end{array}$ & $\begin{array}{l}\text { platelet SERT decreased in } \\
\text { in-lovers and OCD } \\
\text { patients than non-lovers }\end{array}$ & $\begin{array}{c}\text { increase of 5HT though a } \\
\text { suppression of SERT } \\
\text { occurs in early phase } \\
\text { of relationship }\end{array}$ \\
\hline $\begin{array}{l}\text { Marazziti et } \\
\text { al. } 2014 \text { [37] }\end{array}$ & $\begin{array}{l}123 \text { women and } \\
69 \text { men with } \\
\text { depression }\end{array}$ & $\begin{array}{l}\text { SSRIs had a significant } \\
\text { negative impact on the } \\
\text { feelings of love and } \\
\text { attachment towards the } \\
\text { partner especially in men, } \\
\text { while women taking TCAs } \\
\text { complained of more } \\
\text { sexual adversity than men. }\end{array}$ & $\begin{array}{l}\text { SSRI can disturb } \\
\text { romantic love }\end{array}$ \\
\hline $\begin{array}{l}\text { Syvertsen et } \\
\text { al. } 2015 \text { [39] }\end{array}$ & 161 couples & $\begin{array}{l}\text { methamphetamine usage } \\
\text { in female sex workers } \\
\text { reduced the love score to } \\
\text { their male intimate } \\
\text { partners and vice versa. }\end{array}$ & $\begin{array}{l}\text { romantic love is } \\
\text { vulnerable to central } \\
\text { modulating drugs }\end{array}$ \\
\hline \multicolumn{4}{|c|}{ 2. Romantic relationship } \\
\hline $\begin{array}{c}\text { Masarik et al. } \\
2014 \text { [32] }\end{array}$ & 352 adolescence & $\begin{array}{l}\text { ANKK1/DRD2 and DAT } \\
\text { polymorphism } \\
\text { independently predict a } \\
\text { continuity of hostility } \\
\text { from parenting to partner, } \\
\text { whereas the DRD4 } \\
\text { polymorphism of } \\
\text { positive engagement }\end{array}$ & $\begin{array}{l}\text { genetic background relates } \\
\text { in human response to } \\
\text { environmental stress in } \\
\text { both positive and } \\
\text { negative emotion. }\end{array}$ \\
\hline $\begin{array}{l}\text { Raby et al. } \\
2013 \text { [33] }\end{array}$ & $\begin{array}{l}74 \text { female and } 69 \\
\text { male adolescence }\end{array}$ & $\begin{array}{l}\text { attachment continuity } \\
\text { relates to OXTR G/G } \\
\text { genotype only }\end{array}$ & $\begin{array}{l}\text { infantile attachment to } \\
\text { romantic attachment is } \\
\text { modulated by the OXTR } \\
\text { but not DRD } 4 \text { or } \\
\text { 5-HTTLPR }\end{array}$ \\
\hline
\end{tabular}




\section{Continued}

\begin{tabular}{|c|c|c|c|}
\hline $\begin{array}{l}\text { Liu et al. } \\
2014[34]\end{array}$ & 579 Chinese adults & $\begin{array}{l}\text { C-1019G polymorphism } \\
\text { of } 5 \mathrm{HT}-1 \mathrm{~A} \text { gene was } \\
\text { significantly associated } \\
\text { with the odds of being } \\
\text { single both before and } \\
\text { after controlling } \\
\text { psychosocial factors }\end{array}$ & $\begin{array}{l}\text { 5HT-1A gene } \\
\text { influences the social } \\
\text { and romantic behavior }\end{array}$ \\
\hline $\begin{array}{l}\text { Luo et al. } \\
2016 \text { [35] }\end{array}$ & $\begin{array}{c}1532 \text { Chinese } \\
\text { University } \\
\text { students }\end{array}$ & $\begin{array}{l}\text { The } 1 / 1 \text { allele carriers of } \\
\text { 5-HTTLPR reported a } \\
\text { higher satisfaction and a } \\
\text { lower social interaction } \\
\text { anxiety than s/s allele } \\
\text { carriers. }\end{array}$ & $\begin{array}{l}5 \mathrm{HT} \text { in right ventral } \\
\text { prefrontal cortex and } \\
\text { anterior cingulate } \\
\text { gyrus relates to social } \\
\text { and romantic behavior }\end{array}$ \\
\hline
\end{tabular}

Abbreviation: ANKK1/DRD2: ankyrin repeat and kinase domain containing 1 gene/dopamine receptor D2 gene; COMT: catechol-O-methyltransferase; DA: dopamine; DAT: dopamine transporter; DRD4: dopamine receptor D4 gene; 5-HT: serotonin; 5-HTT: serotonin transporter gene; 5-HTTLPR: serotonin transporter linked polymorphic region; mOFC: medial orbitofrontal cortex (mOFC); mPC: medial prefrontal cortex; OCD: obsessive-compulsive disorder; OXTR: oxytocin receptor; SERT: serotonin transporter; SSRI: selective serotonin reuptake inhibitor; TCA: tricyclic antidepressant.

namics in 10 romantic lovers (6 women and 4 men) whose romantic relationships are still stable. The durations of the partnerships range from 2 to 125 months (median 17 months). Compared to visu al-stimulation of the pictures of friends, an increase of activity is significantly detected in the medial orbitofrontal cortex (mOFC) and medial prefrontal cortex (mPC) when lovers viewed the pictures of their romantic partners. The magnitude of excitement correlated to the DAergic activation in mOFC in lovers but not controls (Table 1). Since the mOFC strongly relates to a variety of rewarding experiences [25], including maternal love [26], beauty in face [27] and facial attractiveness [28], an activation in mOFC is rationally observed under romantic relationship. The findings in index study directly implicate that the dopaminergic D2/D3 modulates the rewarding experience of romance in both early and late phase of romantic relationship in human.

\section{Monoamine Transporter and Romantic Love}

Synaptic monoamines are re-uptaken back into the presynaptic neurons in order to regulate the synaptic concentration of monoamines. The DA transporter (DAT), a membrane-spanning protein encoded in chromosome 5 , is highly localized in the mesolimbic, mesocortical and nigrostriatal pathway [29]. An inhibition of DAT will reduce the DA re-uptake and then increase the synaptic DA concentration.

Marazziti et al. [30] measured the lymphocytic DAT level in 30 healthy subjects of equal genders who committed romantic relationship within 6 months and also another 30 healthy subjects who committed a long-lasting relationship. Interestingly, the Bmax (maximal number of receptor bound) and Vmax (the maximum rate achieved at saturating substrate concentration) decreased in early 
phase of romantic relationship. On the other hand, an increase of DA was found in the early phase than the late phase of romantic relationship (Table 1). Accordingly, an increased central DA is considered in the early phase of romantic relationship and that may be responsible for infatuation and other rewarding behaviors.

Marazziti et al. [31] also measured the plateket serotonin transporter (SERT) in 60 subjects ( 20 subjects fell into love within the recent 6 months, 20 unmedicated obsessive-compulsive disorder patients and 20 healthy controls). The SERT was evaluated with the specific binding of $3 \mathrm{H}$-paroxetine (3H-Par) to platelet membranes. The density of $3 \mathrm{H}$-Par binding sites was significantly lower in subjects who had recently fallen in love and in obsessive-compulsive disorder patients than in controls (Table 1). They suggested that the early stage of romantic love and obsessive-compulsive disorder share a common change involving the $5 \mathrm{HT}$ system. Therefore, increased $5 \mathrm{HT}$ obviously displays a beneficial effect on romantic love.

\section{Monoaminergic Receptors, Genetics and Romantic Relationship}

Polymorphism of the dopaminoceptor (DR) genes has been identified in relating to a group of neuropsychiatry disorders and their behaviors. The relationship between polymorphism of DR genes and romantic relationship has also been mentioned in 2 longitudinal studies.

Masarik et al. [32] completed a longitudinal study to investigate the genetic variation of 5 genes, namely the serotonin transporter gene (5-HTT), Ankyrin repeat and kinase domain containing 1 gene/dopamine receptor D2 gene (ANKK1/ DRD2), dopamine receptor D4 gene (DRD4), DAT gene and catechol-O-methyltransferase (COMT) gene, in predicting the altitude to romantic partners after mature with parenting hostility (negative emotion) and positive engagement (positive emotion) experience in adolescence. Participants were interviewed in two separate times, first at adolescence and second at adult 16 years later when they had romantic partners. The hostility and positive engagement between participants and parents were rated at the first interview, and between participants and their partners at the second interview. The results showed that the ANKK1/ DRD2 and DAT polymorphism independently predict a continuity of hostility from parenting to partner, whereas the DRD4 polymorphism of positive engagement (Table 1). These results suggest genetic background displays a key role in human response to environmental stress. The DRD2 and DAT deal with negative emotion whereas DRD4 positive emotion to cope with future romantic partners. Negative emotion, like hostility, may be harmful for romantic love or relationship.

Raby et al. [33] conducted a longitudinal study to investigate the effect of the genotypes of oxytocin receptor (OXTR), DRD4, and serotonin transporter linked polymorphic region (5-HTTLPR) in the continuity of attachment from the early attachment-relevant relationship to adult attachment security. The re- 
sults showed that the continuity of attachment security from infancy into young adulthood was consistently moderated by OXTR genetic variation. Infant attachment security predicted the security of adults' general and romantic attachment representations only for individuals with the OXTR G/G genotype. On the other hand, the DRD4 and 5-HTTLPR genetic variation did not consistently moderate the longitudinal associations between attachment security during infancy and adulthood (Table 1). These findings suggest that the continuity of infantile attachment to romantic attachment is modulated by the OXTR but not DRD4 or 5-HTTLPR. This result is in line with a shifting of DA to oxytocin for a longer romantic relationship.

In regard to 5HT-1A receptor, Liu et al. [34] examined the polymorphism (C-1019G, rs6295) of 5HT-1A gene in 579 Chinese Han people. They found that $50.4 \%$ of individuals with the CC genotype and 39.0\% with CG/GG genotype were in romantic relationship. The $\mathrm{C}-1019 \mathrm{G}$ polymorphism was significantly associated with the odds of being single both before and after controlling for socioeconomic status, external appearance, religious beliefs, parenting style, and depressive symptoms (Table 1 ).

Luo et al. [35] examined the short-short ( $\mathrm{s} / \mathrm{s})$ and long-long (1/l) homozygotes of 5-HTTLPR for romantic relationship satisfaction through a cyberball game that resulted in social exclusion. The $1 / 1$ allele carriers reported a higher satisfaction and a lower social interaction anxiety than s/s allele carriers (Table 1). These results may be due to a control of the right ventral prefrontal cortex and anterior cingulate gyrus during when being excluded from partner.

Nevertheless, these four studies provide important data in that genetic basis contributes to romantic relationship in human.

\section{Monoaminergic Modulators and Romantic Love}

Serotonin-enhancing drugs, such as antidepressants, are known to variably suppress sexual response (libido, arousal and orgasm) [4] but their effect on romantic love is entirely unknown. The sole reason is because love domain has never been studied in most clinical trials before. Although some authors propose antidepressant to have negative impact on romantic effect [36], there is only one clinical trial mentioned about the effect of antidepressants on romantic love.

Marazziti et al. [37] collected 192 depressive patients 123 women and 69 men with mild to moderate severity of depression) who were treated with either a selective serotonin reuptake inhibitor (SSRI) and tricyclic antidepressant (TCA) for at least 6 months and were involved in a romantic love relationship. The mean age was 41.2 years. The change of sexual, attachment and romantic love experience was self-reported and evaluated by the Sex, Attachment, Love (SALT) questionnaire. The results showed that SSRIs had a significant negative impact on the feelings of love and attachment towards the partner especially in men, while women taking TCAs complained of more sexual adversity than men (Table 1). These results firstly demonstrate the negative interaction between drug and romantic love. Importantly, this study supports an influential effect of non- 
psychosocial source on romantic love, especially biochemical alteration of 5HT.

Recreational drugs can change the concentration and activity of central monoamines to produce entactogenic effect in human. For a long time, the methylenedioxyamphetamine (MDA), an analogue of amphetamine and also a metabolite of methylenedioxymethamphetamine (MDMA), is nicked the "Love drug". MDA and MDMA are suggested to engender the feelings of love and warmth [38]. Therefore, recreational drugs are an ideal model to understand the relationship between the central monoamines and romantic love. In indeed, methamphetamine usage in female sex workers reduced the love score to their male intimate partners and vice versa. On the other hand, heroin usage in male intimate partners tended to increase the love score to their female sex worker partner [39] (Table 1). Although methamphetamine and heroin also involve with other neuropeptides and neurotransmitters besides of monoamines, this study still supports that feeling of romantic love is vulnerable for central modulating drugs.

\section{Monoaminergic Regulation of Romantic Love}

In so far, only DA and 5HT are reported in romantic love and satisfaction. The NE, epinephrine, histamine and melatonin are other classical monoamines for neurotransmission. They have been known to participate for the sexual response cycle in human. However, their role in romantic love and satisfaction has not been mentioned yet. Moreover, the trace monoamines have not been investigated in romantic love or relationship.

From the functional neuroimaging studies, the mesocortical and mesolimbic tract are activated during visual or audio stimulation from partner's photo [7]-[15]. The circuit of romantic love is postulated to arise from an activation of ventral tegmentum area and excitatory signal is transmitted to caudate and then frontal lobe, especially the medial prefrontal cortex and orbitofrontal cortex. The activation and deactivation of nucleus accumbens is suggested to modulate the ventral tegmentum area [6] (Figure 2). Since these areas coincide with the mesolimbic and mesocortical tracts, DA is therefore postulated to participate the romantic love. However, biochemical evidence is still lacking.

In this study, the results support DA and 5HT for the biochemical basis of romantic love and relationship. In early phase of romantic relationship, activation of ventral tegmentum area and caudate nuclei associates with an increased DA transmission. This change is responsible to the addictive behaviors, such as obsession, infatuation, preoccupation and aggression. When the DA signal reaches to the medial prefrontal cortex and orbitofrontal cortex, it activates the $5 \mathrm{HT}$ neuron to decrease the suppression on social behaviors, such as passionate action, sexual impulse and closure, and also modulate the affectionate. On the other hand, it either enhances $\left(5 \mathrm{HT}_{1 \mathrm{~A}}\right)$ or retards $\left(5 \mathrm{HT}_{2 \mathrm{~A}}\right.$ or $\left.5 \mathrm{HT}_{2 \mathrm{C}}\right)$ the $\mathrm{DA}$ through different $5 \mathrm{HT}$ subtype receptors. These changes, in turn, modulate the cortical loop to ventral tegmentum area, especially glutamine. The raphe nucleus innervates the ventral tegmentum nucleus through 5HT. Therefore, an increase 


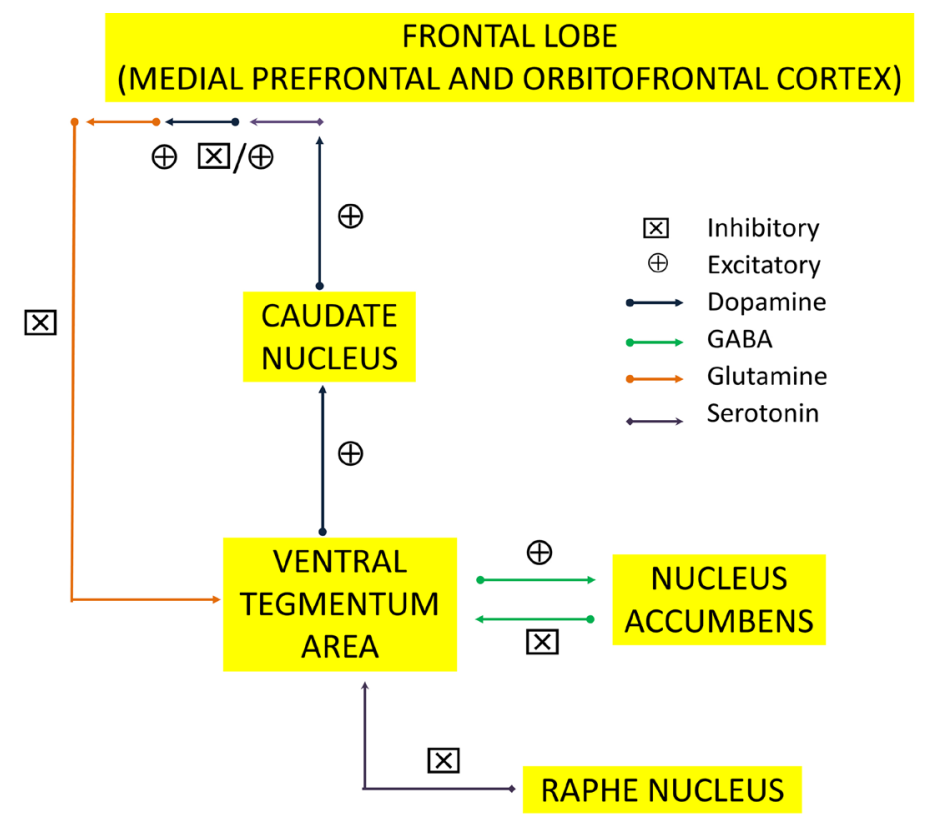

Figure 2. The diagram depicted for the circuit of romantic love and romantic relationship. Currently, romantic love is postulated to arise from the activation of ventral tegmentum. Signal is transmitted to caudate nucleus and then medial prefrontal and orbitofrontal cortex. The cortical loop from frontal lobe and nucleus accumbens serve for feedback on ventral tegmentum area, which is also negatively modulated by raphe nucleus. An increase of DA and 5HT rationally explains the biochemical and behavioral change of these pathways. Increased DA is responsible for the addictive behaviors related to caudate whereas $5 \mathrm{HT}$ for the suppression of social norm from frontal lobe.

of DA and 5HT rationally explains the romantic behaviors in lovers (Figure 2).

Furthermore, polymorphism of DA and 5HT receptor within the mesocorticolimbic tract or frontal lobe will be expected to give an inert response to incoming signal, both the facilitatory and inhibitory. Therefore, polymorphism brings a poor outcome of romantic relationship as the DA and 5HT cannot make appropriate response.

\section{Conclusions}

The interaction between monoamines and romantic love and relationship is neglected before. In aforementioned studies, monoamines are revealed to be able to regulate romantic love at both the cellular and receptor level in human. An increase of synaptic DA and 5HT concentration or activity is documented in romantic lovers, possibly acting through an enhanced terminal release or an inhibition of transporters. Indeed, the use of monoamine-modulating drugs, such as SSRI, TCA and recreational drug, impacts the romantic love in intimate partners. These results remind the possibility of any environmental biological or chemical source that reinforces or ameliorates romantic love through an alteration of central monoamines. On the other hand, the polymorphism of ANKK1/ 
DRD2, DRD4, DAT, 5-HTTLPR and 5HT-1A receptor affects the romantic relationship. These findings indicate a genetic contribution for romantic love. Accordingly, monoamines can regulate romantic love in human at different levels through genetic and non-genetic pathway. Besides of psychosocial impact, the biological impact on romantic love is warranted for further investigation, especially its effect on romantic dissolution and divorce.

\section{References}

[1] Fisher, H. (1992) Anatomy of Love: The Natural History of Monogamy, Adultery and Divorce. Norton, New York.

[2] Eastwick, P.W. (2009) Beyond the Pleistocene: Using Phylogeny and Constraint to Inform the Evolutionary Psychology of Human Mating. Psychological Bulletin, 135, 794-821. https://doi.org/10.1037/a0016845

[3] Jankowiak, W. and Fischer, E. (1992) A Cross-Cultural Perspective on Romantic Love. Ethnology, 31, 149-155. https://doi.org/10.2307/3773618

[4] La Torre, A., Giupponi, G., Duffy, D. and Conca, A. (2013) Sexual Dysfunction Related Topsychotropic Drugs: A Critical Review-Part I: Antidepressants. Pharmacopsychiatry, 46, 191-199. https://doi.org/10.1055/s-0033-1345205

[5] La Torre, A., Conca, A., Duffy, D., Giupponi, G., Pompili, M. and Grözinger, M. (2013) Sexual Dysfunction Related to Psychotropic Drugs: A Critical Review Part II: Antipsychotics. Pharmacopsychiatry, 46, 201-208. https://doi.org/10.1055/s-0033-1347177

[6] Chen, W.H., Kao, Y.C., Chu, M.Y., Chien, C.C. and Chen, K.Y. (2016) The Localization and Operation of Romantic Love in Central Nervous System (Chinese). Studies in Sexuality, 7, 31-60.

[7] Song, H., Zou, Z., Kou, J., Liu, Y., Yang, L., Zilverstand, A., d'Oleire Uquillas, F. and Zhang, X. (2015) Love-Related Changes in the Brain: A Resting-State Functional Magnetic Resonance Imaging Study. Frontiers in Human Neuroscience, 9, 71. https://doi.org/10.3389/fnhum.2015.00071

[8] Acevedo, B.P., Aron, A., Fisher, H.E. and Brown, L.L. (2012) Neural Correlates of Long-Term Intense Romantic Love. Social Cognitive and Affective Neuroscience, 7, 145-159. https://doi.org/10.1093/scan/nsq092

[9] Xu, X., Aron, A., Brown, L., Cao, G., Feng, T. and Weng, X. (2011) Reward and Motivation Systems: A Brain Mapping Study of Early-Stage Intense Romantic Love in Chinese Participants. Human Brain Mapping, 32, 249-257. https://doi.org/10.1002/hbm.21017

[10] Stoessel, C., Stiller, J., Bleich, S., Bönsch, D., Doerfler, A., Garcia, M., RichterSchmidinger, T., Kornhuber, J. and Forster, C. (2011) Differences and Similarities on Neuronal Activities of People Being Happily and Unhappily in Love: A Functional Magnetic Resonance Imaging Study. Neuropsychobiology, 64, 52-60. https://doi.org/10.1159/000325076

[11] Zeki, S. and Romaya, J.P. (2010) The Brain Reaction to Viewing Faces of Opposite and Same-Sex Romantic Partners. PLoS One, 5, e15802. https://doi.org/10.1371/journal.pone.0015802

[12] Kim, W., Kim, S., Jeong, J., Lee, K.U., Ahn, K.J., Chung, Y.A., Hong, K.Y. and Chae, J.H. (2009) Temporal Changes in Functional Magnetic Resonance Imaging Activation of Heterosexual Couples for Visual Stimuli of Loved Partners. Psychiatry Investigation, 6, 19-25. https://doi.org/10.4306/pi.2009.6.1.19 
[13] Aron, A., Fisher, H., Mashek, D.J., Strong, G., Li, H. and Brown, L.L. (2005) Reward, Motivation, and Emotion Systems Associated with Early-Stage Intense Romantic Love. Journal of Neurophysiology, 94, 327-337. https://doi.org/10.1152/jn.00838.2004

[14] Bartels, A. and Zeki, S. (2000) The Neural Basis of Romantic Love. Neuroreport, 11, 3829-3834. https://doi.org/10.1097/00001756-200011270-00046

[15] Ortigue, S., Bianchi-Demicheli, F., Hamilton, A.F. and Grafton, S.T. (2007) The Neural Basis of Love as a Subliminal Prime: An Event-Related Functional Magnetic Resonance Imaging Study. Journal of Cognitive Neuroscience, 19, 1218-1230. https://doi.org/10.1162/jocn.2007.19.7.1218

[16] Yetnikoff, L., Lavezzi, H.N., Reichard, R.A. and Zahm, D.S. (2014) An Update on the Connections of the Ventral Mesencephalic Dopaminergic Complex. Neuroscience, 282, 23-48. https://doi.org/10.1016/j.neuroscience.2014.04.010

[17] García, C.Y. (1998) Temporal Course of the Basic Components of Love throughout Relationships. Psychology in Spain, 2, 76-86.

[18] Marazziti, D. and Canale, D. (2004) Hormonal Changes When Falling in Love. Psychoneuroendocrinology, 29, 931-936. https://doi.org/10.1016/j.psyneuen.2003.08.006

[19] Stárka, L. (2007) Endocrine Factors of Pair Bonding. Prague Medical Report, 108, 297-305.

[20] Berscheid, E. (2010) Love in the Fourth Dimension. Annual Review of Psychology, 61, 1-25. https://doi.org/10.1146/annurev.psych.093008.100318

[21] Esch, T. and Stefano, G.B. (2005) Love Promotes Health. Neuroendocrinology Letters, 26, 264-267.

[22] Eldman, R. (2017) The Neurobiology of Human Attachments. Trends in Cognitive Sciences, 21, 80-99. https://doi.org/10.1016/j.tics.2016.11.007

[23] Coria-Avila, G.A., Manzo, J., Garcia, L.I., Carrillo, P., Miquel, M. and Pfaus, J.G. (2014) Neurobiology of Social Attachments. Neuroscience and Biobehavioral Reviews, 43, 173-182. https://doi.org/10.1016/j.neubiorev.2014.04.004

[24] Takahashi, K., Mizuno, K., Sasaki, A.T., Wada, Y., Tanaka, M., Ishii, A., Tajima, K., Tsuyuguchi, N., Watanabe, K., Zeki, S. and Watanabe, Y. (2015) Imaging the Passionate Stage of Romantic Love by Dopamine Dynamics. Frontiers in Human Neuroscience, 9, 191. https://doi.org/10.3389/fnhum.2015.00191

[25] Rolls, E.T. (2004) The Functions of the Orbitofrontal Cortex. Brain and Cognition, 55, 11-29. https://doi.org/10.1016/S0278-2626(03)00277-X

[26] Bartels, A. and Zeki, S. (2004) The Neural Correlates of Maternal and Romantic Love. Neuroimage, 21, 1155-1166. https://doi.org/10.1016/j.neuroimage.2003.11.003

[27] Ishai, A. (2007) Sex, Beauty and the Orbitofrontal Cortex. International Journal of Psychophysiology, 63, 181-185. https://doi.org/10.1016/j.ijpsycho.2006.03.010

[28] O’Doherty, J., Winston, J., Critchley, H., Perrett, D., Burt, D.M. and Dolan, R.J. (2003) Beauty in a Smile: The Role of Medial Orbitofrontal Cortex in Facial Attractiveness. Neuropsychologia, 41, 147-155. https://doi.org/10.1016/S0028-3932(02)00145-8

[29] Ciliax, B.J., Heilman, C., Demchyshyn, L.L., Pristupa, Z.B., Ince, E., Hersch, S.M., Niznik, H.B. and Levey, A.I. (1995) The Dopamine Transporter: Immunochemical Characterization and Localization in Brain. Journal of Neuroscience, 15, 1714-1723.

[30] Marazziti, D., Baroni, S., Giannaccini, G., Piccinni, A., Mucci, F., Catena-Dell'Osso, M., Rutigliano, G., Massimetti, G. and Dell'Osso, L. (2016) Decreased Lymphocyte Dopamine Transporter in Romantic Lovers. CNS Spectrum, 29, 1-5. 
[31] Marazziti, D., Akiskal, H.S., Rossi, A. and Cassano, G.B. (1999) Alteration of the Platelet Serotonin Transporter in Romantic Love. Psychological Medicine, 29, 741745. https://doi.org/10.1017/S0033291798007946

[32] Masarik, A.S., Conger, R.D., Donnellan, M.B., Stallings, M.C., Martin, M.J., Schofield, T.J., Neppl, T.K., Scaramella, L.V., Smolen, A. and Widaman, K.F. (2014) For Better and for Worse: Genesand Parenting Interact to Predict Future Behavior in Romantic Relationships. Journal of Family Psychology, 28, 357-367. https://doi.org/10.1037/a0036818

[33] Raby, K.L., Cicchetti, D., Carlson, E.A., Egeland, B. and Collins, W.A. (2013) Genetic Contributions to Continuity and Change in Attachment Security: A Prospective, Longitudinal Investigation from Infancy to Young Adulthood. Journal of Child Psychology and Psychiatry, 54, 1223-1230. https://doi.org/10.1111/jcpp.12093

[34] Liu, J., Gong, P. and Zhou, X. (2014) The Association between Romantic Relationship Status and 5-HT1A Gene in Young Adults. Scientific Report, 4, 7049. https://doi.org/10.1038/srep07049

[35] Luo, S., Yu, D. and Han, S. (2016) Genetic and Neural Correlates of Romantic Relationship Satisfaction. Social Cognitive and Affective Neuroscience, 11, 337-348. https://doi.org/10.1093/scan/nsv117

[36] Gold, I. and Olin, L. (2009) From Descartes to Desipramine: Psychopharmacology and the Self. Transcultural Psychiatry, 46, 38-59. https://doi.org/10.1177/1363461509102286

[37] Marazziti, D., Akiskal, H.S., Udo, M., Picchetti, M., Baroni, S., Massimetti, G., Albanese, F. and Dell'Osso, L. (2014) Dimorphic Changes of Some Features of Loving Relationships During Long-Term Use of Antidepressants in Depressed Outpatients. Journal of Affective Disorders, 166, 151-155. https://doi.org/10.1016/j.jad.2014.04.043

[38] Leneghan, S. (2013) The Varieties of Ecstasy Experience: A Phenomenological Ethnography. Journal of Psychoactive Drugs, 45, 347-354. https://doi.org/10.1080/02791072.2013.826561

[39] Syvertsen, J.L., Bazzi, A.R., Martinez, G., Rangel, M.G., Ulibarri, M.D., Fergus, K.B., Amaro, H. and Strathdee, S.A. (2015) Love, Trust, and HIV Risk among Female Sex Workers and Their Intimate Male Partners. American Journal of Public Health, 105, 1667-1674. https://doi.org/10.2105/AJPH.2015.302620

\section{Scientific Research Publishing}

Submit or recommend next manuscript to SCIRP and we will provide best service for you:

Accepting pre-submission inquiries through Email, Facebook, LinkedIn, Twitter, etc. A wide selection of journals (inclusive of 9 subjects, more than 200 journals)

Providing 24-hour high-quality service

User-friendly online submission system

Fair and swift peer-review system

Efficient typesetting and proofreading procedure

Display of the result of downloads and visits, as well as the number of cited articles

Maximum dissemination of your research work

Submit your manuscript at: http://papersubmission.scirp.org/

Or contact asm@scirp.org 